\title{
Impact of Climate Change on Food Crop Production in Congo Brazzaville
}

\section{Edwige Kamitewoko}

Marien Ngouabi University, Brazzaville, Republic of Congo

Email: aijiaae@yahoo.fr

How to cite this paper: Kamitewoko, E. (2021). Impact of Climate Change on Food Crop Production in Congo Brazzaville. Modern Economy, 12, 1686-1702. https://doi.org/10.4236/me.2021.1211085

Received: October 1, 2021

Accepted: November 26, 2021

Published: November 29, 2021

Copyright $\odot 2021$ by author(s) and Scientific Research Publishing Inc. This work is licensed under the Creative Commons Attribution International License (CC BY 4.0).

http://creativecommons.org/licenses/by/4.0/ (c) (i) Open Access

\begin{abstract}
Agriculture is a key for economic transformation, food security, and nutrition. It generates foreign currency through the export process of agricultural products. It creates a source of employment to the population through farming, business and research activities therefore raising the standard of living of individuals. Agriculture, especially food crop production has always been at the mercy of unpredictable weather, but a rapidly changing climate is making agriculture an even more vulnerable enterprise. Food crop production depends on a set of factors which contribute to the increase or decrease of its volume. These factors are essential to guarantee quality production, while others are complementary and serve to improve yields in terms of quality and quantity. However, among these factors, others are difficult to control such as climatic hazards. This study analyzes the impact of climate change on Congo agriculture using data from FAO STAT. Applying Autoregressive-Distributed Lag Regression or ARDL bounds testing approach for analysis of co-integration between the variables, the results reveal that, rainfall depreciates the production of food crops in the long run and has a negative effect on production in the short run; the cultivated area impacts positively food crop production in the long run, but has no effect in the short run. A better understanding of farmers' perceptions of/and responses to climate change is important for decision-makers to design more effective adaptation policies. In order to lowering the drastic impacts of climate change on crop productivity, the study recommends a development of advanced irrigation system, farmers' access to meteorological information and an increase in area under cultivation.
\end{abstract}

\section{Keywords}

Food Crop Production, Climate Change, ARDL, Congo 


\section{Introduction}

In many developing regions, agriculture is of major importance for national economic performance, for example, as expressed by its share in gross domestic product (GDP) (ranging from 30 to 60 percent in about two thirds of them), it employs a large proportion of the labour force (from 40 percent to as much as 90 percent in most cases), represents a major source of foreign exchange (from 25 percent to as much as 95 percent in three quarters of the countries), supplies the bulk of basic food and provides subsistence and other income to more than half of the developing countries population (World Development Report, 2008). Agriculture is and will continue to be the main livelihood for millions of smallholder farmers in Africa and other developing countries across the world. This sector is often deemed a "national security" priority by countries as those products are necessary for existing. However, agricultural production is sensitive to weather and thus directly affected by climate change. Climate change is one of the biggest challenges to the world in present times. It influences all regions of the world, which causes significant perturbations that can be expected to be natural systems that have inevitable impacts on the economic policies of highland areas (Kohler and Maseli, 2012) through both direct and indirect means (Fahad and Jing, 2017).

It is a fact that has been evident around the world, altering the temperature and precipitation, causing changes in environmental conditions, which has affected different sectors, one of the main ones being the agricultural sector, especially in third world countries. Climate change poses a serious threat to natural systems. Growth and development of food crop production are linked to weather, which make them responsive to the specific environments in specific seasons. Global temperature is rising due to human activities such as burning of fossil fuels and clearance of woodlands for building construction. The rise in temperature disrupts crop growth and development.

This phenomenon is likely to contribute substantially to food insecurity in the future, by increasing food prices, and reducing food production. Food may become more expensive as climate change mitigation efforts increase energy prices. Water required for food production may become scarcer due to increased crop water use and drought. Competition for land may increase as certain areas become climatically unsuitable for production. In addition, extreme weather events, associated with climate change may cause sudden reductions in agricultural productivity, leading to rapid price increases.

As a result, different studies (Sleet, 2019; Notezai \& Rehman, 2020; Ullah, 2016; Oxfam, 2019) have been carried out in different countries to gather information on the perceptions information about the effects of climate change on the agricultural. CONGO is a developing country where the technology used to carry out agricultural activities is not viable to face the adverse effects of climate change. This is why it has been important to analyze the effects that climate change has had on that sector, as well as the knowledge that farmers must have about this 
event.

\subsection{Objective}

Given the above situation, the general objective of this study is to intensify the comprehension on the impact of climate change on crop production specifically to determine the effects of temperatures and rainfall on food crops (cassava, beans, bananas, peanuts as well as yam) yield in the CONGO Brazzaville from 1987 to 2016.

\subsection{Organization of the Paper}

The paper is divided into six sections: After introduction, we will state about climate change and agricultural production in chapter two. Following Chapter 2, a theoretical and empirical literature review is conducted in Chapter three. A data and methodological road map is presented in Chapter four. Chapter five outlines the results along with a discussion. Lastly, the final concluding outlines, recommendations are constructed in Chapter six.

\section{Climate Change and Agricultural Production}

In this study, we have chosen five (5) crops including cassava, beans, bananas, groundnuts and yams to analyze the impact of climate change on agricultural production. We select the five crops because all of them have almost identical characteristics seeing their temperature and rainfall requirements. Besides, these crops are projected to remain stable under moderate and extreme climate change scenarios.

In African countries such as Congo a large part of the population is dependent on agricultural production (crops) as a means of substance and food security, but this production is influenced by climatic factors (rainfall and temperature).

\subsection{Link between Food Crop Production and Rainfall}

Water is a key input to agricultural production and therefore fluctuations in water availability may impact agricultural productivity and revenue. All crops need water to grow and produce yields. The most important source of water for crop growth is rainfall which guarantee a good harvest.

At the beginning of planting, crops need a rainfall range from 1200 to 1500 $\mathrm{mm}$ to allow germination, fertilization, development of the seed (groundnut and bean) or roots (yam, cassava and banana). Investment promotion agency (2017) states that the Republic of Congo is one of the most watered countries in the African continent, with an annual rainfall varying between 1200 and $1500 \mathrm{~mm}$ of water per year, and with a vast hydrographic network organized around two main basins: the Congo River basin in the north and the Kouilou-Niari River, which flows southwestward.

The rising temperature would expose millions of people to drought and hunger. Climatic variability and change have always presented a threat to food secu- 
rity in Congo through their effect on rainfall, soil moisture and production.

The increase in rainfall variability has a major effect on inter-annual changes in food crop yields. Excessive rainfall is expected to further restrict access to water resources, shorten the growing season, alter the agricultural calendar of farmers, and even impact soil fertility. This phenomenon is likely to jeopardize the efforts made by countries to achieve food security and will lead to malfunctioning of agricultural seasons, disruption of crop biological cycles and deterioration of agricultural production. Thus, crop yields will generally decrease in the tropics and subtropics (André et al., 2003).

Frequential analysis of rainfall indices seems to be very useful for defining an agricultural strategy, by contrasting the appropriate response in the probability of obtaining the quantities of water that the crops will need during their cycle.

Figure 1 shows that the rainfall amount is unstable throughout the study period, evolving in a sawtooth pattern. The lowest rainfall amounts were observed in 1997 and 2004 (999.8 $\mathrm{mm}$ and $1134.7 \mathrm{~mm}$ respectively). The highest rainfall amount is observed first in 1990 with $1778.9 \mathrm{~mm}$ while reaching a peak in 2007 with $1852.8 \mathrm{~mm}$ which remains the most considerably observed.

This can be explained by the fact that the Republic of Congo is subject to strong rainfall variations due to global factors, regional and continental dynamics. Heavy rainfall means that the rains feed an abundant hydrography, which makes the Republic of Congo a hydro-morphic country. Thus, this excess of rainfall in time and space is the cause of the rainfall calendar disruption that negatively impacts and causes water stress and risks on agricultural yields (Doukpolo, 2014).

\subsection{Relationship between Food Crop Production and Temperature}

Both temperature and rainfall play an important role in the production of these crops; during flowering, development, growth and harvesting. They require temperatures ranging from $15^{\circ} \mathrm{C}$ to $27^{\circ} \mathrm{C}$ on days as well as nights (GIEC, 2007).

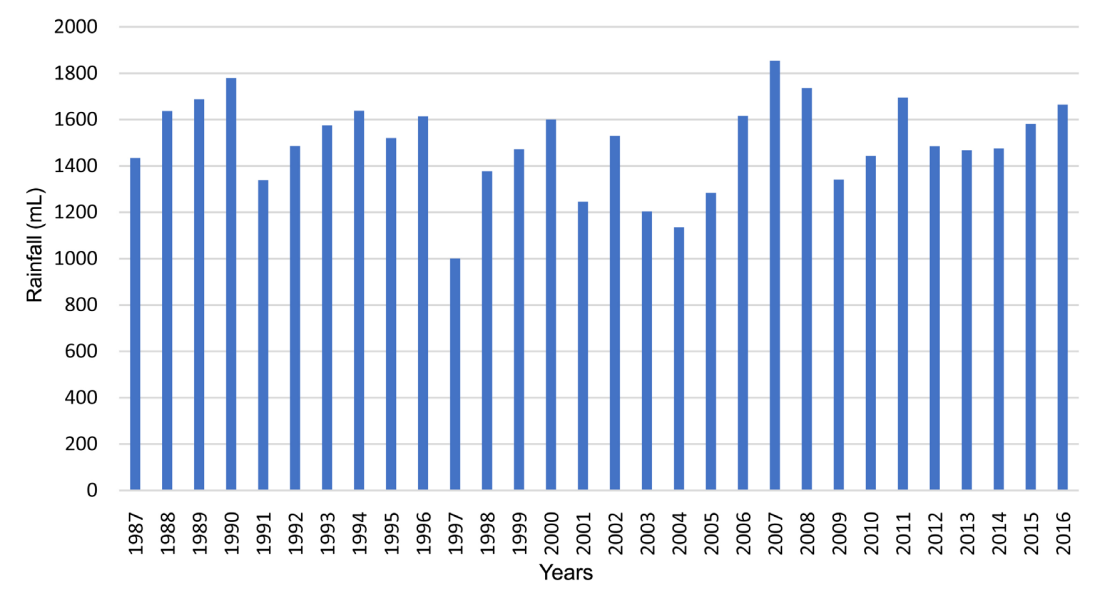

Figure 1. Evolution of rainfall in mm per year. Sources: ANAC and Congo Statistical Yearbooks 2018. 
According to FAO (2008), another factor favoring the production of these crops is their potential ability to adapt to climate change. The study conducted by the FAO about the impact of climate change showed that some crops are more vulnerable compared to others (cassava especially), so these crops can tolerate long dry periods. In addition, global warming threatens agricultural production.

Rise in average temperature can trigger plant diseases while increasing water stress, which consequently decreases crop.

Agriculture yields could decrease by $50 \%$ in some countries by 2022; and net crop income by $90 \%$ by 2100 (Somorin et al., 2010).

\subsection{Food Crop Production}

Agriculture in the Congo is traditional with rudimentary means, it is an itinerary agriculture on bushes (old traditions). The agricultural sector is based more essentially on food crops (cassava, plantain, beans, yams, corn, peanuts); among which we have the cassava crop as the main one in the country, it is the crop that produces more (in 2016 it made yields up to 1,445,318 tons throughout the national territory) and occupies more than $50 \%$ of the cultivated area (FAO, 2012).

The Congo's soils constitute a vast exploitation area. There is 10 million hectares of available arable land, but only $2 \%$ are exploited or 200,000 hectares. In fact, Crop productivity is low in Congo when compared with developed economies. This is due to rural exodus, application of outdated approaches to farming, poor irrigation systems, and a poor adoption of up-to-date agricultural technologies. This situation result in the small savings or low-income levels of rural households. Consequently, formal financial intuitions need to offer financial support so that farmers can adopt and use more-advanced farm practices. Formal agricultural credit plays a central role in boosting crop production. This sector is more practiced by women, who represent about $70 \%$ of the country's active agricultural population (FAO, 1996).

\section{Literature Review}

We will first state about a theoretical Review and then present empirical studies.

\subsection{Theoretical Review}

The ideology for quantifying the impacts of climate change on agricultural production at the global, regional and national levels began to develop in the early 1980s and continues nowadays. Since then, several achievements have been made in this same perspective of trying to model more realistically the impact of climate change on the agricultural sector.

This ideology emanates from the various currents of economic thought before and after the industrial revolution.

Physiocracy, one of the earliest currents marking the emergence of political economy, at the end of the eighteenth century, places nature at the heart of wealth 
production, as shown by the very term "physiocracy"-literally, "government by nature". Its leader, François Quesnay, considered the earth as the only one source of wealth, and agriculture as the only activity worthy of interest in an economy. He praised the multiplicative power of the earth and considered peasants the only productive class, with merchants and industrial entrepreneurs constituting the "sterile" class.

For the physiocrats, humanity is subjected to nature. The only means of prospering is therefore to respect its constraints; and the economist's duty is to reveal its laws-a set of postulates which may make the physiocrats look like one of the first "eco" movements in economics. The classical school succeeds that of the physiocrats. Here nature also holds a preponderant place, but from a very different perspective. This current emerges in a changed context. We are at the turn of the nineteenth century, at the moment when the industrial revolution is beginning, for the classical school, nature has no value in itself, but only acquires value through human work and its commercialization. Nevertheless, some of them are conscious of natural environment limits: they fear that, one day, growth will end, as resources are exhausted. This is why Thomas Malthus states that the population level must never go beyond the capacity of the earth to ensure its subsistence

For Adam Smith and Ricardo, the limited availability of natural resources could, in part, be overcome by way of an optimized organization of work and the development of international commerce. With the Ricardian method, land values or net revenues are regressed on climate, soils, geographic variables and economic variables that are independent of the farmer (not choices). The approach is a cross-sectional analysis. The method captures the locus of net revenues across each climate. It presumes that farmers adjust their inputs, outputs and farming practices to best take advantage of where the farm is located, including the climate. The Ricardian model is a comparative static analysis. It reflects all the adjustments that farmers and ecosystems have made in response to climate. It is a measure of the long-term consequences of climate change. Jean-Baptiste Say was to go even further: for him, the question of the exhaustion of natural resources had no place.

Joseph Stiglitz, far from resolving the question of the treatment of the environment in standard theory, will allow the concept of weak sustainability to be born. Solow and Hartwick will extend the concept of capital to all of nature. According to them, the economy functions by virtue of three types of capital: physical capital (machines, infrastructure), human capital (humans and their skills), and natural capital (the entirety of natural resources). For an economy to be sustainable, the sum of these three capitals must be at least constant. Decrease in one of them can be compensated by the accumulation of another, since they are understood to be substitutable: if a natural resource is totally exhausted, it is possible to compensate for this loss by investing more in a substitute resource. For example, when petrol runs out, it will suffice to have invested enough beforehand in wind power. 


\subsection{Empirical Review}

Agriculture is one of the sectors most affected by ongoing climate change. The wide range of literature on this subject demonstrates that damages caused by climate change can be relevant to both cropping and livestock activities (Aragón et al., 2021; Adams et al., 1995). Climate change will have a significant effect on the rural landscape and the equilibrium of agrarian and forest ecosystems (Walker and Steffen, 1997; Bruijnzeel, 2004; Solomon, Simane, and Zaitchik, 2021). In fact, climate change can affect different agricultural dimensions, causing losses in productivity, profitability and employment. Food security is clearly threatened by climate change (Innes, Denton, Dundas, Peck, \& Humphries, 2021; Chamhuri et al., 2013), due to the instability of crop production, and induced changes in markets, food prices and supply chain infrastructure. Moreover, because of the multiple socio-economic and bio-physical factors affecting food systems and, consequently food security, the capacity to adapt food systems to reduce their vulnerability to climate change is not uniform from a spatial point of view (Gregory et al., 2005). However, besides its primary role in producing food and fibers, agriculture performs also other functions, such as the management of renewable natural resources, the construction and protection of landscape, the conservation of biodiversity, and the contribution to maintain socioeconomic activities in marginal and rural areas. Climate change could affect also this multifunctional role of agriculture (Xuan, Liu, \& Zhang, 2021). Thus, many believe that the largest effects of climate change will be on agriculture. However, under the conditions of climate change, agriculture production rises in the higher latitudes, partly because of an increase in arable land, and production tends to fall in the tropics, mainly due to an assumed decline in the availability of water (Cooper, 2000; Parry et al., 2007). Gregory, Ingram and Brklacich (2005) suggested that climate change was playing an important role for agriculture but its relative importance varied among regions as well as among different societal groups within a region.

\section{Methodology}

The data used in this paper is from the secondary source (FAO STAT, 2017). We use a dual econometric analysis to analyze the impact of climate change on food crops in Congo between 1987 and 2016 (a period of 30 years). We will first test the stationarity of the series and the residuals through an error correction model (ECM). And, in the second time test the presence of a cointegration relation by estimating an autoregressive model with staggered delays (ARDL, Pesaran and Shin, 1998).

\section{The Autoregressive Distributed Lag Procedure}

- The autoregressive model (AR): it is a dynamic model where we find, among the explanatory variables $\left(X_{t}\right)$, the lagged dependent variable (its past values). A simple model to incorporate such dynamic effects has the following form: 


$$
Y_{t}=f\left(X_{t}, Y_{t-p}\right)
$$

The term "autoregressive" means self-regressed"

The Distributed Lag (DL) Model We say that the value of the dependent variable, at a given point in time, should depend not only on the value of the explanatory variable at that time period, but also on the values of the explanatory variable in the past. A simple model to incorporate such dynamic effects has the form:

$$
Y_{t}=f\left(X_{t}, X_{t-q}\right)
$$

- Staggered lag autoregressive models (ARDL): these models combine the characteristics of the two previous ones; they include, among the explanatory variables $\left(X_{t}\right)$, the lagged dependent variable $\left(Y_{t-p}\right)$ and the past values of the independent variable $\left(X_{t-q}\right)$. They have the following general form:

$$
Y_{t}=f\left(X_{t}, Y_{t-p}, X_{t-q}\right)
$$

Hallam and Zanoli (1993) indicate that the absence of prior verification of the stationarity hypothesis limits the econometric results validity in the context of dynamic modeling optimization behavior. The analysis of the impact of climate change in our study is thus based on the ARDL model of Pesaran et al. (2001). The model chosen is the one presented by Ouattara (2017) who worked on the analysis of the dynamics raw cashew nuts in Côte d'Ivoire, which used as endogenous variable the production of cashew nuts (y) and as exogenous variables: the price of cashew nuts, the cultivated area, the export rate and the trend (which captures governance, climate, infrastructure); and $\mu$ the error term, based on the Cobb-Douglas function.

$$
Y=f(K, L)
$$

The number of lags of the dependent and explanatory variables is selected using the Schwartz Information Criterion (SIC):

$$
Y(t)=\alpha+\beta X(t)+\mu(t)
$$

This is our reference model:

$$
L Y=\alpha+L P_{t}^{a}+L S U P+L E X P+L T R_{t}+\varepsilon_{t}
$$

Apart from some of the variables used by Ouattara (2017), we considered food crop production as an endogenous variable, rainfall in height, average temperature and cultivated area as exogenous variables.

Hence The relationship between Food crop production and Rainfall, Average temperature and Cultivated area can be specified as:

$$
P C v_{t}=\alpha+\beta_{1} \text { Pluvio }_{t}+\beta_{2} \text { Tmoy }_{t}+\beta_{3} \text { Supc }_{t}+\mu_{t}
$$

where:

$P_{C V}$ is Food crop production; $\alpha$ is Constant; Pluvio is Rainfall in height

Tmoy is Average temperature; Supc is Cultivated area

After processing the data, it was found that the mean of temperature variable 
was not significant, which led us to exclude it from our equation and to retain only two exogenous variables, namely: rainfall in height and cultivated area. Thus our equation is designed as follows:

$$
\text { Pcv }_{t}=\alpha+\beta_{1} \text { Pluvio }_{t}+\beta_{2} \text { Supc }_{t}+\mu_{t}
$$

\section{Results}

Before reporting the results of the ARDL model: we test the stationarity of the series.

\subsection{Study of Variables Stationarity}

The time series analysis commonly begins with a stationarity study of the concerned variables. We use three (3) categories of the most widespread tests namely: the Augmented Dickey-Fuller (ADF) test, the Phillips-Perron (PP) test and the Kwiatkwoski, Phillips, Smidt and Shin (KPSS) test, whose null hypothesis is non-stationarity. Thus, the results for the endogenous variable (food crop production) and its fundamentals (rainfall in height and cultivated area) are reported in Table 1.

The results of the Augmented Dickey Fuller (ADF), Phillips-Perron (PP) and Kwiatkwoski, Phillips, Smidt and Shin (KPSS) unit root tests show that the endogenous variable and the exogenous variables are stationary in first difference at $5 \%$ threshold. They must therefore be differentiated twice to make them stationary.

Besides, these results suggest that all the variables are integrated of order one i.e. stationary after first difference and give support to the use of ARDL bounds approach to determine the long-run relationships among the variables.

\subsection{Bound Testing}

The model will be estimated by a new cointegration technique proposed by Pesaran et al. (2001), namely Autoregressive Distributed Lag (ARDL), to overcome the limitations of conventional cointegration methods (Engle and Granger, 1987; Johansen, 1991). The advantage of the ARDL method, in contrast to the latter, can be found on two levels. On the one hand, it can be applied to any degree of integration of the variables used: purely I (0), purely I (1) or mixed. On the

Table 1. Stationarity tests.

\begin{tabular}{|c|c|c|c|c|c|c|c|}
\hline Tests & \multicolumn{2}{|c|}{$\mathrm{ADF}$} & \multicolumn{2}{|c|}{$\mathrm{PP}$} & \multicolumn{2}{|c|}{ KPSS } & \multirow[b]{2}{*}{ decision } \\
\hline Variables & t-statistic & $\begin{array}{c}\text { Critical value } \\
\qquad(5 \%)\end{array}$ & $t$-statistic & $\begin{array}{c}\text { Critical value } \\
\qquad(5 \%)\end{array}$ & $t$-statistic & $\begin{array}{l}\text { Critical value } \\
\qquad(5 \%)\end{array}$ & \\
\hline Production cv & -6.316707 & -2.976263 & -15.76611 & -2.971853 & 0.351101 & 0.463000 & I (1) \\
\hline Pluvio in ht & -4.007977 & -2.967767 & -3.907654 & -2.967776 & 0.138113 & 0.463000 & $\mathrm{I}(0)$ \\
\hline Superficie & -5.609843 & -2.971853 & -5.774175 & -2.971853 & 0.260434 & 0.463000 & I (1) \\
\hline
\end{tabular}

Source: Author from the results obtained on Stata 14. 
other hand, it has statistical properties for small samples (Cheung and Lai, 1993). The ARDL method is relatively more efficient for small samples, as is the case for most empirical studies of developing countries. the ARDL test does not require the model variables to be purely I (0) or I (1). It is also a technique that offers the possibility of dealing jointly with long-run dynamics and short-run adjustments. We have therefore adopted this approach for the analysis of the dynamic relationship between the explanatory factors of cashew nut supply. Unit root tests are performed for the variables using the ADF test, to study the stationarity of the variables in their degree of integration. Then, the model is analyzed using the Autoregressive-Distributed Lag procedure, due to the need to take stock of the long-run and short-run consequences of our analysis. ARDL modeling with the appropriate lags will correct for the two problems of correlation and endogeneity of the series. Another reason for using the ARDL approach is that it is more robust and performs better for small sample sizes than other cointegration techniques.

However, in order to apply the ARDL Bound testing method, one must be sure that there are no variables I (2).

\subsection{Validation of the Model}

The results of the robustness tests show that the null hypothesis cannot be accepted for all the tests and therefore the residuals meet the conditions of validity of the model, namely the absence of autocorrelation, the existence of normality and homoscedasticity. Moreover, the CUSUM and CUSUM squared tests show that the estimated parameters are stable over the study period (Figure 2 and Figure 3).

1) Boundary co-integration test based on ARDL model: Bounds test

The cointegration test of the long-run relationship between food crop production and exogenous variables is done using the new ARDL boundary test procedure "Bounds tests" used by Pesaran et al. (2001) in the ARDL models.

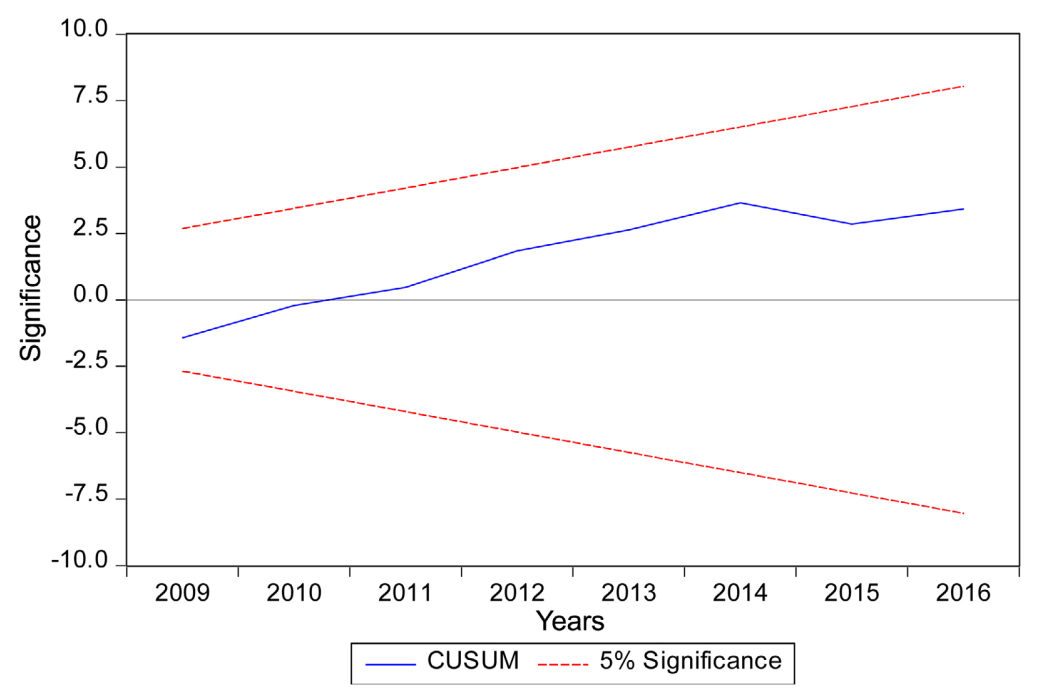

Figure 2. CUSUM test. 


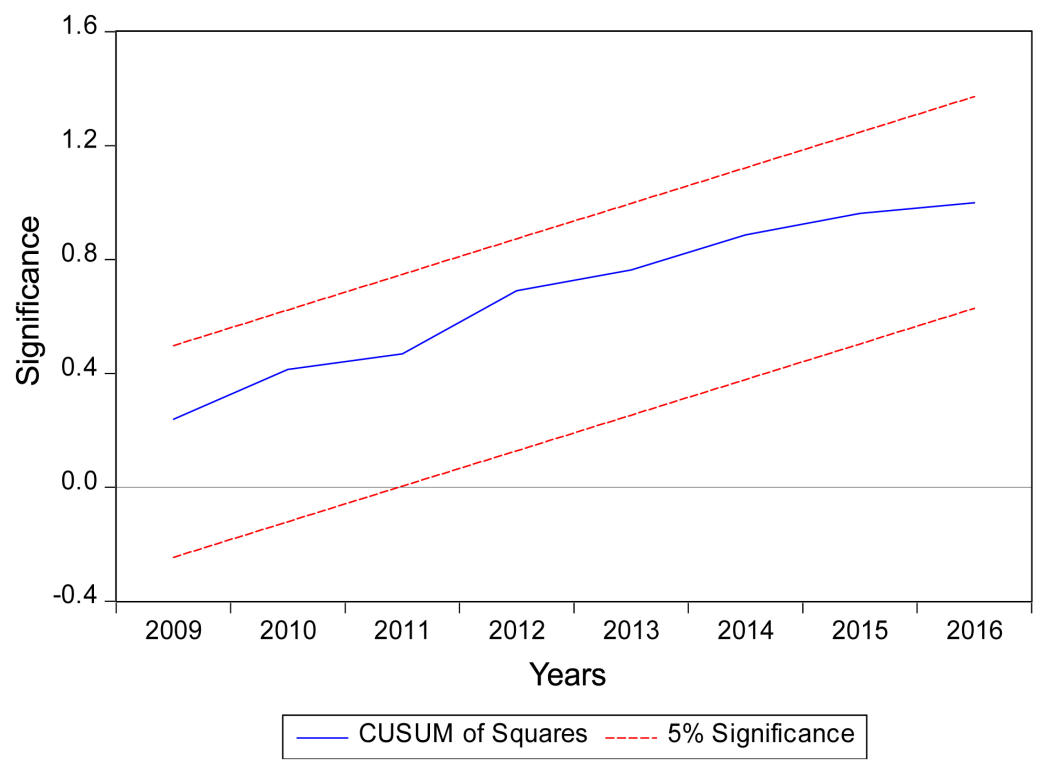

Figure 3. CUSUM squared tests.

Table 2 below presents the ARDL "Bounds tests" results.

Table 2 provides values for the Bounds test which uses Fisher's test to test the cointegration hypotheses. Thus, we test the null hypothesis for the absence of cointegration against the alternative hypothesis of the existence of cointegrating relationships in the Naranyan (2005) approach for small samples. The test procedure is such that we will have to compare the values of the bounds with the Fisher value. If the Fisher value is higher than the upper bound, the null hypothesis is rejected, while in the opposite case, the null hypothesis is accepted.

It appears from the Bounds test table that the Fisher statistic which takes the value of (10.54) is higher than the upper bound which is (5.3). Then we reject the null hypothesis H0 (absence of cointegration relationship) and accept the alternative hypothesis of existence of cointegration relationship between the selected variables. This evidence of the existence of cointegrating relationships therefore allow us to proceed with the estimation of the long- and short-term relationships of our ARDL cointegration model.

\section{2) Short- and long-term relationships: cointegration ARDL}

The estimates obtained in Table 3, show that the adjustment coefficient is negative and statistically significant, which shows the existence of an error correction mechanism and consequently a long-term relationship between the variables, the value of this coefficient is 1.38 , which testifies to a $138 \%$ misalignment of agricultural production (food crops) from its equilibrium.

In the first part of the table, the variable rainfall in height has a negative effect on production in the short term; a $1 \%$ increase in rainfall in height will lead to a $224 \%$ depreciation in production and does not seem to change its effect over time. The other significant variable is that of cultivated area, for which no effect is shown in the short term and seems to stop there. 
Table 2. Bounds tests.

\begin{tabular}{ccc}
\hline \multicolumn{3}{c}{ Naranyan (2005) } \\
\hline \multicolumn{2}{c}{ Null Hypothesis: No long-run relationships exist } \\
\hline statistic test & Value & $\mathrm{K}$ \\
\hline F-statistic & 10.54916 & 2 \\
& Critical Value Bounds & \\
Significance & I0 Bound & I1 Bound \\
$10 \%$ & 2.17 & 3.19 \\
$5 \%$ & 2.72 & 3.83 \\
$2.5 \%$ & 3.22 & 4.5 \\
$1 \%$ & 3.88 & 5.3 \\
\hline
\end{tabular}

Source: Author based on Eviews 9 results.

Table 3. Estimation of short- and long-term relationships.

ARDL Cointegrating And Long Run Form

Dependent Variable: AGRICULTURAL_PRODUCTION_TON

Selected Model: ARDL $(1,6,6)$

Sample: $1987-2016$

\begin{tabular}{|c|c|c|c|c|}
\hline \multicolumn{5}{|c|}{ Cointegrating Form } \\
\hline Variable & Coefficient & Std. Error & $t$-Statistic & Prob. \\
\hline D (PLUVIO_HT_MM_) & -444.376332 & 237.581483 & -1.870417 & 0.0983 \\
\hline D (PLUVIO_HT_MM_(-1)) & -223.925942 & 286.499650 & -0.781592 & 0.4570 \\
\hline D (PLUVIO_HT_MM_(-2)) & -242.345686 & 312.373925 & -0.775819 & 0.4602 \\
\hline D (PLUVIO_HT_MM_(-3)) & -458.327050 & 288.534482 & -1.588465 & 0.1508 \\
\hline D (PLUVIO_HT_MM_(-4)) & -184.959310 & 275.392784 & -0.671620 & 0.5207 \\
\hline D (PLUVIO_HT_MM_(-5)) & 170.794168 & 249.191356 & 0.685394 & 0.5125 \\
\hline D (SCULTIVEE_HA_) & 7.789101 & 8.610024 & 0.904655 & 0.3921 \\
\hline D (SCULTIVEE_HA_(-1)) & -7.629402 & 6.532451 & -1.167923 & 0.2765 \\
\hline D (SCULTIVEE_HA_(-2)) & -4.323182 & 4.800186 & -0.900628 & 0.3941 \\
\hline D (SCULTIVEE_HA_(-3)) & -4.328167 & 4.973365 & -0.870269 & 0.4095 \\
\hline D (SCULTIVEE_HA_(-4)) & -10.702610 & 5.084927 & -2.104772 & 0.0684 \\
\hline D (SCULTIVEE_HA_(-5)) & -13.423137 & 5.638536 & -2.380607 & 0.0445 \\
\hline CointEq $(-1)$ & -1.381301 & 0.261409 & -5.284060 & 0.0007 \\
\hline \multicolumn{5}{|c|}{$\begin{array}{c}\text { PRODUCTION_TON }-(-607.043999 * \text { PLUVIO_HT_MM_+ }+11.360289 * \\
\text { CULTIVATED_AREA_HA }+175151.4064)\end{array}$} \\
\hline \multicolumn{5}{|c|}{ Long Run Coefficients } \\
\hline
\end{tabular}


Continued

\begin{tabular}{ccccc}
\hline Variable & Coefficient & Std. Error & t-Statistic & Prob. \\
PLUVIO_HT_MM_ & -607.043999 & 1048.477372 & -0.578977 & 0.5785 \\
CULTIVATED_AREA_HA_ & 11.360289 & 2.573054 & 4.415099 & 0.0022 \\
C & $175,151.406448$ & $1,402,093.201965$ & 0.124921 & 0.9037
\end{tabular}

Source: Author based on results from Eviews 9.

In the same table, the lower part provides us the coefficients in the long term, the results show that in the long-term rainfall in height is significant and depreciates the production of food crops, indeed these results are similar to those of Ouédraogo (2012) on the case of farmers in Burkina Faso and this may be different in developed countries, so a $1 \%$ increase in rainfall leads to a depreciation of production by $607 \%$.

The other significant variable is the cultivated area which positively impacts food crop production, a $1 \%$ increase in cultivated area can lead to an appreciation of food crop production by $11.36 \%$, this is in phase with results found by Ouattara (2017) as well as by other studies that have focused on developing countries.

Economic interpretation of the results.

\subsection{Rainfall}

Rainfall has a negative impact on food crop production. An increase in this variable leads to a decrease in production, all other things being equal. On the one hand, an increase in rainfall has an influence on the productive capacity of farmers, by modifying the agricultural calendar and reducing the land fertility. On the other hand, this situation increases the cost of production, by submerging the seeds to the point of rotting and drowning them, resulting in lower production.

This expected result is similar to the empirical results of Kurukulasuriya \& Mendelsohn (2007).

Similarly, according to World Bank (2013), excess rainfall influences the rainy season (start and end dates, duration, amount of rainfall). The rainfall pattern could indirectly affect agricultural systems. Changes in rainfall could exacerbate existing inequalities in water availability between regions and increase the isolation of aquifers in some crop production areas, limiting agricultural production.

\subsection{Cultivated Area}

Land area has a positive influence on food crop production, i.e., an increase of one unit of land area leads to an increase in food crop production of $11.36 \%$.

Land is the main factor in any production, whatever the area and whatever the techniques used, in agriculture the land factor has a linear relationship with the volume of production (if there is no soil, there will be no production).

The effect of land area on food crop production is positive, but does not gen- 
erally improve the productivity of the land (the rent). This can be explained by the large areas owned by some farmers in the region, as the average area per farmer is about $1.5 \mathrm{ha} /$ capita. This leads to a drop in yield due to a lack of financial resources for the maintenance and exploitation of large areas, because the larger the area of cultivable land owned, the less maintenance is done to try to increase productivity and thus proportionally increase production.

Agricultural production is driven more by the increase in cultivated areas than by the increase in yields (Doukpolo, 2014).

These results are similar to those obtained by the FAO in its report "World Agriculture: Horizon 2015-2030.

\section{Conclusion and Policy Implications}

This paper provides a brief overview of the situation of Congolese agriculture during the period 1987-2016, with a particular focus on food crop agriculture. The objective of our study was to analyze the impact of climate change on food crop production from 1987 to 2016 in Congo Brazzaville using data obtained from FAO STAT data base for the period of 1987-2016. We selected five (5) food crops, namely cassava, yam, banana, groundnut and bean.

Applying Autoregressive-Distributed Lag Regression or ARDL bounds testing approach for analysis of co-integration between the variables, the empirical results reveal that, in the long run, rainfall in height is significant and depreciates the production of food crops; the cultivated area impacts positively food crop production, and, in the short run, rainfall in height has a negative effect on production; cultivated area, has no effect.

To significantly reverse the weight of national supply in relation to imports, several actions or policies need to be carried out, among others:

- Allocate more land to these crops either by creating new public food farms and/or by encouraging farmers and investors in this field to create private farms;

- Increase the area dedicated to food crops and ensure a good distribution of land;

- Modernize agricultural equipment, and strengthen advice and technical support for farmers;

- Promote the dissemination and use of climate information.

\section{Conflicts of Interest}

The author declares no conflicts of interest regarding the publication of this paper.

\section{References}

Adams, R. M., Fleming, R. A., Chang, C.-C., McCarl, B. A., \& Rosenzweig, C. (1995). A Reassessment of the Economic Effects of Global Climate Change on US Agriculture. Climatic Change, 30, 147-167. https://doi.org/10.1007/BF01091839

André, P., Delisle, C. E., \& Revéret, J.-P. (2003). L'évaluation des impacts sur l'environ- 
nement. Processus, acteurs et pratique pour un développement durable (2ème éd.). Presses Internationales Polytechnique.

Aragón, F. M., Oteiza, F., \& Rud, J. P. (2021). Climate Change and Agriculture: Subsistence Farmers' Response to Extreme. Heat American Economic Journal: Economic Policy, 13, 1-35. https://doi.org/10.1257/pol.20190316

Bruijnzeel, L. A. (2004). Hydrological Functions of Tropical Forests: Not Seeing the Soil for the Trees? Agriculture Ecosystems \& Environment, 104, 185-228. https://doi.org/10.1016/j.agee.2004.01.015

Chamhuri, S., Ahmed, F., \& Ara Begum, R. (2013). Climate Change, Agriculture and Food Security Issues: Malaysian Perspective. Journal of Food Agriculture and Environment, 11, 1118-1123.

Cooper, R. N. (2000). International Approaches to Global Climate Change. The World Bank Research Observer, 15, 145-172. https://doi.org/10.1093/wbro/15.2.145

Doukpolo, B. (2014). Thèse sur le Changement climatique et production agricole dans I'Ouest de la Centrafrique (p. 16, 23, 28, 29, 34, 35, 44). Université d'Abomey Calavi (Laboratoire Pierre PAGNET).

Engle, R. F., \& Granger, C. W. (1987). Co-Integration and Error Correction: Representation, Estimation, and Testing. Econometrica, 55, 251-276. https://doi.org/10.2307/1913236

Fahad, S., \& Jing, W. (2017). Evaluation of Pakistani Farmers' Willingness to Pay for Crop Insurance Using Contingent Valuation Method: The Case of Khyber Pakhtunkhwa Province. Land Use Policy, 72, 570-577. https://doi.org/10.1016/j.landusepol.2017.12.024

FAO (Food and Agriculture Organization of the United Nations) (1996). World Food Day, Fighting Hunger and Malnutrition (p. 16). Food and Agriculture Organization of the United Nations.

FAO (Food and Agriculture Organization of the United Nations) (2008). Rapport de la 33ème session annuelle du comité de la sécurité alimentaire mondiale (p 125).

FAO (Food and Agriculture Organization of the United Nations) (2012). Bases de données statistiques de l'Organisation des Nations Unies pour l'alimentation et l'agriculture (FAOSTAT). Food and Agriculture Organization of the United Nations.

FAO STAT (2017). Food and Agriculture Data, Bases de données statistiques de l'Organisation des Nations Unies pour l'alimentation et l'agriculture. https://www.fao.org/faostat/fr/\#home

Gregory, P. J., Ingram, J. S. I., \& Brklacich, M. (2005). Climate Change and Food Security. Philosophical Transactions of the Royal Society B. Biological Sciences, 360, 2139-2148. https://doi.org/10.1098/rstb.2005.1745

G-ROC (Government-Republic of Congo) (2017) Investment Promotion Agency. https://apicongo.org/agriculture.php

Hallam, D., \& Zanoli, R. (1993). Error Correction Models and Agricultural Supply Response. European Review of Agricultural Economics, 20, 151-166.

Innes, L. A., Denton, M. D., Dundas, I. S., Peck, D. M., \& Humphries, A. W. (2021). The Effect of Ploidy Number on Vigor, Productivity and Potential Adaptation to Climate Change in Annual Medicago Species. Crop Science, 61, 89-103.

https://doi.org/10.1002/csc2.20286

IPCC (Intergovernmental Panel on Climate Change) (2007). Climate Change 2007. Synthesis Report. Contribution of Working Groups I, II and III to the Fourth Assessment Report of the Intergovernmental Panel on Climate Change (p. 16, 104). Intergovernmental Panel on Climate Change. 
Johansen, S. (1991) Estimation and Hypothesis Testing of Cointegration Vectors in Gaussian Vector Autoregressive Models. Econometrica, 59, 1551-1580.

https://doi.org/10.2307/2938278

Kohler, T., \& Maseli, D. (2012). Mountains and Climate Change-From Understanding to Action (3rd ed., p. 12, 14). Geographica Bernensia.

Kurukulasuriya, P., \& Mendelsohn, R. (2007). A Ricardian Analysis of the Impact of Climate Change on Africa Cropland. World Bank Policy Research Paper No. 4305. Washington DC: World Bank.

Narayan, P. K. (2005). The Saving and Investment Nexus for China: Evidence from Cointegration Tests. Applied Economics, 37, 1979-1990.

https://doi.org/10.1080/00036840500278103

Notezai, M., \& Rehman, A. (2020, May 11). Locust Attacks Threatens Food Security in Pakistan. Dawn. https://www.dawn.com/news/1555487

Ouattara, G. M. (2017). Les déterminants de l'adoption de certaines bonnes pratiques culturales avant récolte de la noix de cajou en Côte d'Ivoire. IOSR Journal of Economics and Finance, 8, 8-15.

Ouedraogo, M. (2012). Impact des changements climatiques sur les revenus agricoles au Burkina Faso. Journal of Agriculture and Environment for International Development.

Oxfam (2019, December 2). Forced from Home: Climate-Fuelled Displacement. Oxfam Media Briefing.

https://reliefweb.int/sites/reliefweb.int/files/resources/mb-climate-displacementcop25021219-en 0.pdf

Parry, M. et al. (2007). Climate Change 2007: Impacts, Adaptation and Vulnerability. Contribution of Working Group II to the Fourth Assessment Report of the Intergovernmental Panel on Climate Change. Cambridge University Press.

Pesaran, M. H., \& Shin, Y. (1998) An Autoregressive Distributed-Lag Modelling Approach to Cointegration Analysis. Econometrics and Economic Theory in the 20th Century: The Ragnar Frisch Centennial Symposium, 31, 371-413.

Pesaran, M.H., Shin, Y., \& Smith, R.J. (2001). Bounds Testing Approaches to the Analysis of Level Relationships. Journal of Applied Econometrics, 16, 178-191.

https://doi.org/10.1002/jae.616

Sleet, P. (2019, September 25). Water Resources in Pakistan: Scarce, Polluted and Poorly Governed. Future Directions International Pty Ltd.

https://www.futuredirections.org.au/publication/pakistan-needs-to-improve-water-qua lity-for-public-and-economic-health/

Solomon, R., Simane, B., \& Zaitchik, B. (2021). The Impact of Climate Change on Agriculture Production in Ethiopia: Application of a Dynamic Computable General Equilibrium Model. American Journal of Climate Change, 10, 32-50.

https://doi.org/10.4236/ajcc.2021.101003

Somorin, O. (2010). Climate Impacts, Forest-Dependent Rural Livelihoods and Adaptation Strategies: A Review. African Journal Environ Science and Technology, 4, 903-912

Ullah, W. (2016). Climate Change Vulnerability of Pakistan towards Natural Disasters: A Review. International Journal of Environmental Protection and Policy, 4, 126-132. https://doi.org/10.11648/j.ijepp.20160405.13

Walker, B., \& Steffen, W. (1997). An Overview of the Implications of Global Change for Natural and Managed Ecosystems: A Synthesis of GCTE and Related Research. Conservation Ecology, 1, 2. https://doi.org/10.5751/ES-00028-010202

World Bank (2013). Annual Freshwater Withdrawals, Agriculture (Percentage of Total 
Freshwater Withdrawal). http://data.worldbank.org/indicator/ER.H2O.FWAG.ZS

World Development Report (2008). Agriculture for Development. World Bank Publications. http://siteresources.worldbank.org/INTWDR2008/Resources/WDR 00 book.pdf

Xuan, X., Liu, B., \& Zhang, F. (2021). Climate Change and Adaptive Management: Case Study in Agriculture, Forestry and Pastoral Areas. Land, 10, Article No. 832.

https://doi.org/10.3390/land10080832 